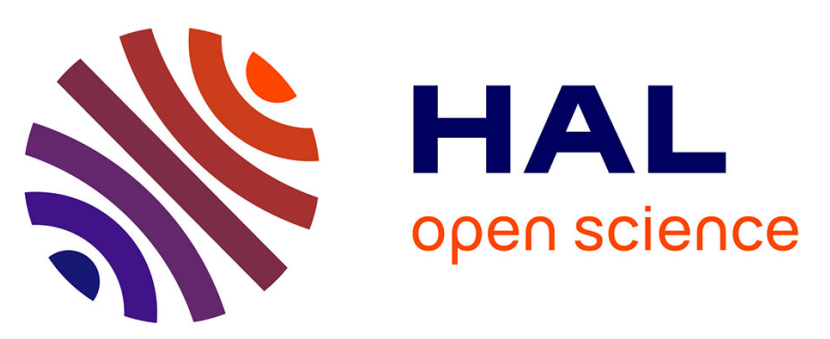

\title{
Pollinator Specific Richness and Their Interactions With Local Plant Species: 10 Years of Sampling in Mediterranean Habitats
}

Lise Ropars, Laurence Affre, Matthieu Aubert, Catherine Fernandez, Floriane Flacher, David Genoud, Frédéric Guiter, Coline C Jaworski, Xavier Lair, Clémentine Mutillod, et al.

\section{To cite this version:}

Lise Ropars, Laurence Affre, Matthieu Aubert, Catherine Fernandez, Floriane Flacher, et al.. Pollinator Specific Richness and Their Interactions With Local Plant Species: 10 Years of Sampling in Mediterranean Habitats. Environmental Entomology, 2020, 49 (4), pp.947-955. 10.1093/ee/nvaa061. hal-02869143

\section{HAL Id: hal-02869143 \\ https://hal-amu.archives-ouvertes.fr/hal-02869143}

Submitted on 17 Jun 2020

HAL is a multi-disciplinary open access archive for the deposit and dissemination of scientific research documents, whether they are published or not. The documents may come from teaching and research institutions in France or abroad, or from public or private research centers.
L'archive ouverte pluridisciplinaire HAL, est destinée au dépôt et à la diffusion de documents scientifiques de niveau recherche, publiés ou non, émanant des établissements d'enseignement et de recherche français ou étrangers, des laboratoires publics ou privés. 
doi: 10.1093/ee/nvaa061

\title{
Pollinator Ecology and Management
}

\section{Pollinator Specific Richness and Their Interactions With Local Plant Species: 10 Years of Sampling in Mediterranean Habitats}

\author{
Lise Ropars, ${ }^{1,5, \bullet}$ Laurence Affre, ${ }^{1}$ Matthieu Aubert, ${ }^{2}$ Catherine Fernandez, ${ }^{1}$ \\ Floriane Flacher, ${ }^{1}$ David Genoud, ${ }^{2}$ Frédéric Guiter, ${ }^{1}$ Coline Jaworski, ${ }^{1,3}$ Xavier Lair, ${ }^{4}$ \\ Clémentine Mutillod, ${ }^{1}$ Gabriel Nève, ${ }^{1}$ Lucie Schurr, ${ }^{1}$ and Benoît Geslin ${ }^{1}$
}

${ }^{1}$ IMBE, Aix Marseille Univ, Avignon Université, CNRS, IRD, Marseille, France, ${ }^{2}$ Observatoire des Abeilles, 68 rue du Onze Novembre, 59148 Flines-lez-Raches, France, ${ }^{3}$ Department of Zoology, University of Oxford, Oxford, United Kingdom, ${ }^{4} 3$ Quartier du Pujol, 66730 Sournia, France, and ${ }^{5}$ Corresponding author, e-mail: lise.ropars@imbe.fr

Received 20 January 2020; Editorial decision 6 May 2020

\begin{abstract}
In the context of global pollinator decline, little is known about the protection status and ecology of many species. This lack of knowledge is particularly important for Mediterranean protected areas that harbor diverse pollinator communities and are subject to considerable anthropogenic pressures. Calanques National Park $\left(85 \mathrm{~km}^{2}\right)$, which is located near Marseille (France), is dominated by Mediterranean low-vegetation habitats, such as phrygana and scrublands. These habitats offer favorable conditions for pollinator species due to the important amount of floral resources. Within a 10-yr period, we recorded bee (Hymenoptera: Apoidea: Anthophila), hover fly (Diptera: Syrphidae), and bee fly (Diptera: Bombyliidae) species and their interactions with the local flora through 10 field campaigns. We caught 250 pollinator species, including 192 bees, 38 hover flies, and 20 bee flies, for a total of 2,770 specimens. We recorded seven threatened bees (six near threatened and one endangered). Among the bee species, $47.9 \%$ were below-ground nesting species, and $54.7 \%$ were generalist species. Analysis of the pollination network showed that generalist and specialist pollinators do not share the same floral resources. The Cistaceae plant family (Malvales: Cistaceae) acted as a central node in the plant-pollinator network, interacting with 52 different pollinator species, which shows the importance of large open flowers that could be easily visited by both short and long-tongued pollinators in Mediterranean habitats. The occurrence of pollinator species and their ecological traits should strongly contribute to reinforcing the available information to provide or ameliorate the conservation statuses determined by IUCN Red List.
\end{abstract}

Key words: Apoidea, Syrphidae, Bombyliidae, biodiversity, conservation

Insect pollinators are essential for the reproduction of wild plants and crops (Ollerton et al. 2011). In Europe, the species richness of insect pollinators increases along a north-south gradient, with a maximum reached around the Mediterranean basin (Nieto et al. 2014). The Mediterranean basin is considered a biodiversity hotspot (Médail and Quézel 1997) and hosts a large diversity of plant species, which can benefit a wide richness of pollinator species (Dafni and O'Toole 1994). This hotspot, however, suffers from many types of anthropogenic pressure, such as land use change (fragmentation, increasing urbanization), pollution (nearby cities, past industrial activity), agricultural practices (grazing), climate change (Giorgi and Lionello 2008) and intentional or accidental wildfires (Petanidou and Ellis 1997). To address the conservation of species within Mediterranean ecosystems, large areas have been included in protected national parks. However, there are still knowledge gaps related to the pollinating fauna in Mediterranean protected ecosystems. As an example, the IUCN European Red List of bees indicates that, for at least $38 \%$ of the wild bee species of French Mediterranean ecosystems, there is not enough data to state their conservation status (Nieto et al. 2014, Rasmont et al. 2017). Considering the current biodiversity loss and the crucial importance of pollinators in the functioning of ecosystems, it is urgent to develop a better understanding of the community composition of pollinating fauna in addition to their distributions, ecological traits, and interactions with plant species.

In European and Mediterranean ecosystems, bees and flies are the most dominant pollinators responsible for the reproduction of many flowering plants (Ollerton 2017). Bees are key pollinators because they rely on nectar and pollen at both adult and larval stages. Each bee family is characterized by specific functional traits related 
to the way they collect pollen and nectar, such as their tongue length and specific pollen collection structures (e.g., pollen baskets on honey bees and bumble bee species, flocculus on Andrena species, and abdominal scopa on Megachilidae). In France, the INPN national taxonomic database referenced 962 wild bee species in 2019 (Gargominy et al. 2019). The IUCN European Red List estimated the occurrence of approximately 720 species in southern France, most of which are endemic to the Mediterranean basin (Nieto et al. 2014). Furthermore, as well as harboring a large diversity of plants, Mediterranean habitats offer many nesting resources for wild bee species due to the dry climate, which limits vegetation cover and thus results in more available bare soil (Nielsen et al. 2011). Consequently, the composition of wild bee species and their ecology and interactions with the local floral might be very specific but are still poorly known.

Regarding nonbee species such as hover flies, the 540 known species in the French territory also strongly contribute to pollination (Rader et al. 2016). Hover flies are considered bio-indicators of natural habitats because of their various ecological niches, mainly during their larval stage, role as pollinators, and sensitivity to pesticides and landscape composition (Sommaggio 1999). As larvae, hover fly species have various diets, including saprophagous, insectivorous, phytophagous, or mycophagous diets, and may then occupy many ecological niches. As adults, most hover fly species seek floral resources (pollen and nectar). Among nonbee species, bee flies also contribute to pollination services. Their larvae parasitize the brood of wild hymenopteran species (Merritt et al. 2009), whereas adults collect and feed on nectar and pollen. According to the INPN national taxonomic database, 150 bee fly species have been recorded in France (Gargominy et al. 2019), but only two recent works on their distribution or ecology have been published (Zaitzev 2007, 2008).

Generalist species are of particular importance as they occupy a central position in plant-pollinator networks. They are usually considered as key species because they have an important role to support the coexistence of both plants and pollinators (Pocock et al. 2011, Bartomeus 2013). Indeed, considering their floral diet, some pollinator species are generalists and collect floral resources from a wide range of plant species, whereas specialist pollinator species rely on few plant species. The arrangement, diversity, and strength of links between plant and pollinator species are indicators of the stability of pollination networks and may be linked with the sustainability of ecosystems (Memmott et al. 2004). In plant-pollinator networks, generalist plant and pollinator species could contribute to increasing the stability of the network, especially by multiplying the number of links with the other levels, including specialist plant species (Martín González et al. 2010). In contrast, pollinator species that forage on only one plant species and plant species visited by only one pollinator species are the most vulnerable (Weiner et al. 2014). Each change in these interactions could affect the structure of the whole network and, therefore, plant and pollinator populations. However, in Mediterranean ecosystems, despite that few plant-pollinator networks have been described, these generalist species are poorly known.

In this study, we intend to improve the knowledge on pollinator communities by focusing on bee, hover fly, and bee fly species and their relationships with plant species in Mediterranean low-vegetation habitats. Through a 10-yr sampling effort (from 2009 to 2018) in a protected area (Calanques National Park), we explored the following questions: (i) What is the species richness of bees, hover flies, and bee flies in low-vegetation Mediterranean habitats and what is their protection status? (ii) What are the dominant ecological and functional traits of these pollinating species? (iii) What floral resources are included in their diets, and what is structure of the whole pollination network?

\section{Materials and Methods}

\section{Study Site and Pollinator Surveys}

All observations and captures were conducted in Calanques National Park (near Marseille, France-4 $43^{\circ} 13^{\prime} \mathrm{N}, 5^{\circ} 28^{\prime} \mathrm{E}$ ). This area is characterized by typical Mediterranean low-vegetation habitats (western Mediterranean phrygana, Astragalo-Plantaginetum subulatae, and shrubland) and by Mediterranean forests and rocky habitats. The western Mediterranean phrygana corresponds to the sclerophyll cushion associations typical of Mediterranean coastal areas (Molinier 1934). This protected biodiversity hotspot of 85 $\mathrm{km}^{2}$ hosts more than 900 plant species (Pires and Pavon 2018), and the dominant entomophilous species are Rosmarinus officinalis $\mathrm{L}$. (Lamiales: Lamiaceae), Cistus albidus L. (Malvales: Cistaceae), and Thymus vulgaris L. (Lamiales: Lamiaceae) in shrubland (Flo et al. 2018). The Mediterranean climate is characterized by hot and dry summers, rainy autumns, and mild winters. The main flowering season stretches from February to June.

Over a period of 10 years (2009-2018), 10 sampling campaigns were carried out within this protected area (Table 1). These sampling campaigns were all conducted when meteorological conditions were favorable for pollinator activity (i.e., only on sunny days with wind $<20 \mathrm{~km} / \mathrm{h}$ and temperature $>15^{\circ} \mathrm{C}$ ). Pollinators were caught either through entomological nets or pan traps or both (Table 1). The net collection of insects consisted of catching insects in densely flowered patches for 5 to $10 \mathrm{~min}$ and repeating the action at least two times for each sampling site (Fig. 1). The pan trap collection was carried out by laying three colored pan traps for a $24 \mathrm{~h}$ period following the method of Westphal et al. (2008). Plastic bowls of $500 \mathrm{ml}$ were painted with blue, white, or yellow paint that reflected UV light to mimic flowers and passively attract flower visitors. Each pan trap was filled with soapy water and placed on the ground; the pans were placed $1 \mathrm{~m}$ apart from each other in a triangle arrangement. Pan trap collection underestimates the occurrence of large pollinators because they are better able to escape the trap than smaller species. Net collection underestimates the presence of small pollinators due to the reduced ability of humans to detect them (Wilson et al. 2008, Popic et al. 2013). These two methods are thus complementary and can be combined for a better estimation of pollinator diversity (Westphal et al. 2008). All ecological traits, such as nesting habits and lectism of wild bee species, are reported in Supp Table 1 (online only) according to the expertise of D. Genoud and M. Aubert (Carré 2008, Lugassy 2016, Genoud 2017, Geslin et al. 2018, Ropars et al. 2018).

The first four sampling campaigns were conducted by X. Lair and M. Aubert between 2009 and 2011. They consisted of onetime bee surveys (Samplings 1 to 4). In May 2016, a collective 3-d sampling campaign was completed as part of a training course on wild bees (Sampling 5) (Geslin et al. 2018). Between 2017 and 2018 (Samplings 6 to 9), more intensive surveys were carried out every week for 2-5 mo (Schurr et al. 2019, Ropars et al. 2020). Finally, D. Genoud performed a one-time bee species survey in May 2018 (Sampling 10). The pan traps were only used in Sampling 9 in 2018 in addition to the net surveys. Details of each sampling campaign are provided in Table 1 .

The total species richness was estimated with the Chao and jackknife methods and included all captures (Gotelli and Colwell 2011). The Chao1 index estimates the potential maximum species number in an area based on the species that are observed only once or twice. The jackknife index is a resampling technique that decreases the estimator bias by deleting some of the observations. We calculated these indexes using the function ChaoSpecies() within the Spade-R 
Table 1. Details of each sampling effort conducted from 2009 to 2018 within Calanques National Park

\begin{tabular}{|c|c|c|c|c|c|c|c|c|}
\hline $\begin{array}{l}\text { Sampling } \\
\text { campaign }\end{array}$ & Taxa caught & Capture method & $\begin{array}{c}\text { Number of } \\
\text { capture sessions }\end{array}$ & Date & $\begin{array}{l}\text { Number of } \\
\text { sites }\end{array}$ & Collector & $\begin{array}{c}\text { Pollen } \\
\text { analyses }\end{array}$ & $\begin{array}{c}\text { Networks } \\
\text { data }\end{array}$ \\
\hline 1 & Bees and hover flies & Net & One-time & April 2009 & 4 & X. Lair & & \\
\hline 2 & Bees & Net & One-time & May and June 2009 & 3 & M. Aubert & & \\
\hline 3 & Bees & Net & One-time & May and July 2010 & 2 & M. Aubert & & \\
\hline 4 & Bees & Net & One-time & Feb. and April 2011 & 3 & M. Aubert & & \\
\hline 5 & Bees & Net & One-time & May 2016 & 3 & $\begin{array}{l}\text { Bee course attendants } \\
\text { (Geslin et al. 2018) }\end{array}$ & & \\
\hline 6 & Bees and hover flies & Net & Weekly & Mar.-April 2017 & 6 & $\begin{array}{c}\text { L. Schurr } \\
\text { (Schurr et al. 2019) }\end{array}$ & & $\mathrm{X}$ \\
\hline 7 & $\begin{array}{c}\text { Bees, hover flies, and } \\
\text { bee flies }\end{array}$ & Net & Weekly & Feb.-June 2017 & 17 & L. Ropars & $\mathrm{X}$ & $\mathrm{X}$ \\
\hline 8 & $\begin{array}{c}\text { Bees, hover flies, and } \\
\text { bee flies }\end{array}$ & Net & Weekly & Mar.-June 2018 & 6 & C. Jaworski & & $\mathrm{X}$ \\
\hline 9 & $\begin{array}{l}\text { Bees, hover flies, } \\
\text { and bee flies }\end{array}$ & Net and Pan traps & Weekly & Feb.-June 2018 & 17 & L. Ropars & $\mathrm{X}$ & $\mathrm{X}$ \\
\hline 10 & Bees & Net & One-time & May 2018 & 2 & D. Genoud & & \\
\hline
\end{tabular}

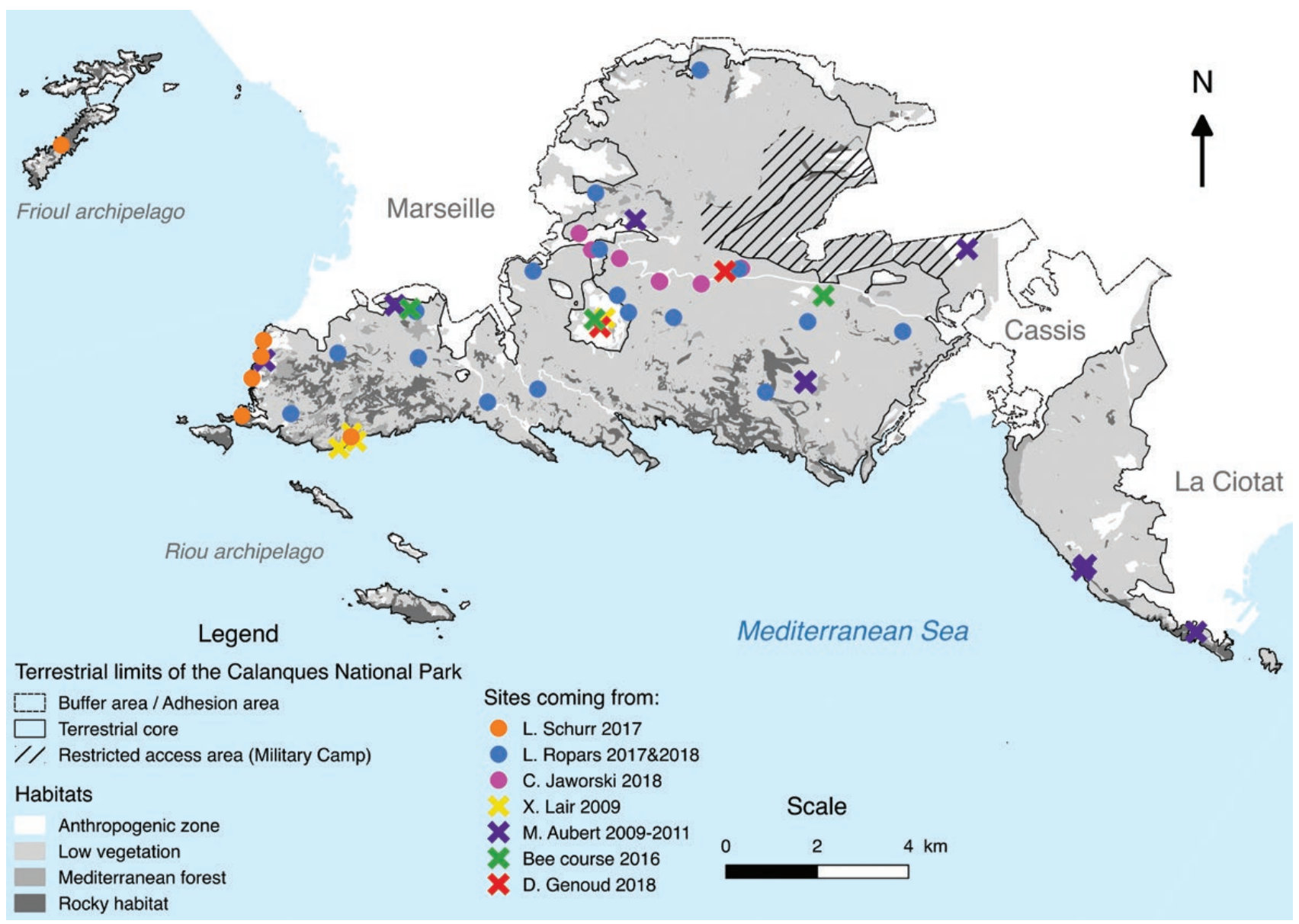

Fig. 1. Terrestrial limits and habitats of Calanques National Park. Crosses and dots correspond to each sampling plot. Crosses correspond to one-time inventories (only one session performed), whereas dots correspond to regular inventories (at least two sessions per year).

package in R version 3.6 software (Chao et al. 2016, R Core Team 2019).

\section{Plant-Pollinator Interactions}

The plant-pollinator network was built using two successive methods: (i) direct observations and individual insect captures on plant species and (ii) reconstruction of the a posteriori network through an analysis of pollen grains carried by pollinator species. For part (i), we based our global qualitative plant-pollinator network on net samplings on plant species (Samplings 6 to 9 only). Collectors also conducted sessions in which they observed insect visits on plant species without catching them to assess the floral diet of pollinators. For 
part (ii), pollen grains carried by the sampled bees during Samplings 7 and 9 were collected on their pollen collecting structures. Pollen grains were then acetolysed following the protocol of Faegri and Iversen (1975) to reveal their ornamentation for identification. They were mixed with glycerol and mounted on slides to be identified to the family and, if possible, to the genus and species using a reference atlas (Reille 1999). The pollen analysis was conclusive for only 72 bee individuals, and few links completed the whole pollination network which was not sufficient to compare both pollen and capture networks. The overall plant-pollinator interaction network for the bee, hover fly and bee fly species, including all the interactions from (i) and (ii), was built with the bipartite package (Dormann et al. 2009) available on the R software (R Core Team 2019). For the remaining samplings, pollinators not linked with a plant species (e.g., caught by pan trap or while flying) were not considered.

Using the obtained network, we calculated its modularity, nestedness, number of compartments, and connectance as main descriptors using the computeModules() and networklevel() functions from the bipartite package (Dormann et al. 2009, R Core Team 2019). The modularity highlights the groups of species that interact preferentially together, and its value ranged between 0 (random links between species) and 1 (strong community structure) (Barber 2007). Nestedness is indicated when a specialist species interacts with a subset of the species used by generalists species (Mariani et al. 2019). It is expressed as a percentage where the maximum value corresponds to a perfect nested structure. Finally, the connectance corresponds to the proportion of observed interactions relative to the maximum number of potential interactions in the network and ranges between 0 and 1 (Poisot and Gravel 2014).

\section{Results}

\section{Bee Species Diversity}

From 2009 to 2018, 192 bee species (Hymenoptera: Apoidea: Anthophila) were caught in Calanques National Park via both net and pan trap collections. They belonged to six families and 38 genera. Megachilidae was the most species-rich family, followed by Apidae and Halictidae, with 53, 44, and 43 species, respectively. Andrena Fabricius, 1775 was the richest genus, with 33 species, whereas eight genera were represented by only one species (Stelis Panzer, 1806; Protosmia Ducke, 1900; Pseudoanthidium Friese, 1898; Coelioxys Latreille, 1809; Chelostoma Latreille, 1809; Anthidiellum Cockerell, 1904; Amegilla Friese, 1897; Panurgus Panzer, 1806; Supp Table 1 [online only]). Using the jackknife 1 and 2 indexes, the total bee species richness was estimated to be between $240.98 \pm 9.89$ and $268.96 \pm$ 17.13. The observed richness thus represented 71.3 to $79.6 \%$ of the estimated bee richness (Table 2). The Chao1 method estimated the observed richness to be $76.8 \%$ of the potential maximum richness

Table 2. Richness estimations of hover fly, bee fly, and bee species

\begin{tabular}{|c|c|c|c|c|}
\hline \multirow{2}{*}{$\begin{array}{l}\text { Groups } \\
\text { Variables }\end{array}$} & \multicolumn{2}{|c|}{ Hover flies and bee flies } & \multicolumn{2}{|c|}{ Bees } \\
\hline & Values & $\begin{array}{c}95 \% \\
\text { Confidence } \\
\text { interval }\end{array}$ & Values & $\begin{array}{c}95 \% \\
\text { Confidence } \\
\text { interval }\end{array}$ \\
\hline Abundance & 219 & - & 2,551 & - \\
\hline Number of species & 58 & - & 192 & - \\
\hline Chao1 & 86 & {$[69 ; 134]$} & 250 & {$[220 ; 310]$} \\
\hline Jackknife1 & 83 & {$[72 ; 101]$} & 241 & {$[225 ; 264]$} \\
\hline Jackknife2 & 97 & {$[79 ; 129]$} & 269 & {$[242 ; 310]$} \\
\hline
\end{tabular}

(Table 2). The most abundant species was Apis mellifera L. (276 individuals), followed by Rhodanthidium septemdentatum (Latreille, 1809), Rh. sticticum (Fabricius, 1787) (174 and 168 individuals, respectively), and Lasioglossum transitorium (Shenck, 1868) (113 individuals). Finally, 50 species ( $26 \%$ ) were represented by only one individual (singletons).

\section{Ecological Traits of Bees}

Regarding the ecological traits of nesting preferences, we identified 59 solitary bee species nesting above ground, 92 solitary bee species nesting below ground and 23 cleptoparasitic species, corresponding to $30.7,47.9$, and $12.0 \%$ of the total bee species richness, respectively. We detected four social species (bumble bees and honey bees-2.1\%). Finally, the nesting preferences of 14 species remain unknown (7.3\%-Supp Table 1 [online only]). Regarding the floral diet of bee species, we found that 105 species $(54.7 \%)$ foraged on a wide range of plant species (i.e., generalist species, polylectic) and 51 species $(26.5 \%)$ foraged on one plant family or one/few plant species (i.e., specialist species, oligolectic). For the remaining 36 bee species $(18.8 \%)$, the floral diet was not known (e.g., for cleptoparasitic species). However, most generalist species showed a preference for one or a few plant families (Supp Table 1 [online only]). For the 49 singletons, 14 bee species (28\%) were specialists, and 9 bee species (18\%) were cleptoparasitic (Supp Table 1 [online only]).

An IUCN status was available for 178 species (excluding the species complexes and unidentified species). Among those, 47 species were classified as data deficient (DD-26.4\%), 124 species were least concerned (LC-69.6\%), six species were near threatened (NT-3.4\%; Andrena ovatula (Kirby, 1802), Colletes albomaculatus (Lucas, 1849), Dasypoda argentata Panzer, 1809, Halictus quadricinctus (Fabricius, 1776), Lasioglossum prasinum (Smith, 1848), and L. pygmaeum (Schenck, 1853)), and one species was considered endangered (EN-0.6\%; L. soror (Saunders, 1901)—Supp Table 1 [online only]). Three oligolectic species were among the seven threatened bee species. A. ovatula and C. albomaculatus are specialists on Fabaceae, D. argentata is a specialist on Caprifoliaceae.

\section{Hover Fly and Bee Fly Species Diversity}

From 2009 to 2018, 38 species of hover flies (Diptera: Syrphidae) were caught in Calanques National Park. They belonged to 24 genera (Supp Table 2 [online only]). The most abundant genera were Paragus Latreille, 1804 (33 individuals), Meliscaeva Frey, 1946 (14 individuals), and Sphaerophoria Lepeletier de Saint-Fargeau \& Audinet-Serville in Latreille, 1828 (13 individuals), whereas 20 species $(53 \%)$ were represented by only one individual (Supp Table 2 [online only]). The bee flies (Diptera: Bombyliidae) were represented by 20 species, including five singletons (25\%) (Supp Table 3 [online only]). The estimation of total species richness of hover flies and bee flies was between 83 and 97 species using the jackknife 1 and 2 indexes, respectively. Consequently, the observed richness represented $59.8-69.9 \%$ of the estimated hover fly and bee fly richness (Table 2).

\section{EcologicalTraits of Hover Flies and Bee Flies}

Bee fly species correspond to parasitic species of Hymenoptera species including wild bees, but their hosts and their ecology are not well known. Regarding the captured hover flies, their larvae were mostly zoophagous (23 species), only two species were phytophagous, and three species were both phytophagous and zoophagous. Hover fly larvae of 24 species $(63 \%)$ were nontolerant to inundations. At the adult stage, 27 species of hover flies preferentially foraged on pollen 
and nectar flowers (corresponding to $73 \%$ of the whole inventory) (Supp Table 2 [online only]).

\section{Plant-Pollinator Interaction Network}

The complete network included 133 pollinator species in interaction with 62 plant species, representing 314 different links (Fig. 2). The network had six compartments: five blocks with one plant species linked to one or two pollinator species and one block with the remaining plant and pollinator species. The modularity, nestedness, and connectance of the network were estimated at $0.50,12.96$, and 0.04 respectively.

The highly generalist pollinator species were A. mellifera, $R h$. septemdentatum, $R$ h. sticticum, L. transitorium, L. bimaculatum (Dours, 1872), and Paragus tibialis (Fallén, 1817), which foraged on $14,12,11,11,10$, and 10 plant species, respectively (Fig. 2). On the other hand, the plant species visited by a high diversity of pollinators were C. albidus and Ro. officinalis, with 37 and 35 pollinator species, respectively (Fig. 2). Twenty plant species were visited by only one pollinator species, and the mean shared pollinator species per plant was 5.06 species.

\section{Discussion}

\section{Species Richness of the Mediterranean Pollinator Community}

For this study to the best of our knowledge, we compiled all available surveys of pollinators within Calanques National Park from 2009 to 2018 . We found 250 pollinator species, including 192 bee, 38 hover fly, and 20 bee fly species. This corresponded to 20,7 , and $13 \%$ of the bee, hover fly, and bee fly species, respectively, that have been described in France. The highest abundance and diversity of pollinators was sampled when both weekly net and pan trapping were used to catch pollinators in the Mediterranean low-vegetation habitats (Nielsen et al. 2011).

The species richness found in this study indicates that Mediterranean low-vegetation habitats can support a high richness of pollinators. In another protected area located at $70 \mathrm{~km}$ east of Calanques National Park (Port-Cros National Park), CoiffaitGombault et al. (2018) found a similar species richness of 162 bee species and 26 hover fly species (Gombault et al. 2018). In Greece, from $4 \mathrm{yr}$ of net and Malaise samplings within Mediterranean low-vegetation habitats, 262 bee species, 59 hover fly species, and 47 bee fly species were documented (Petanidou and Ellis 1993, Petanidou et al. 2011). This richness of pollinator assemblages is, therefore, close to the scores given by the Chao and jackknife indexes for bees (Chao1 = 250 species; Jackknife $2=269$ species), hover flies and bee flies (Chao1 = 85 species; Jackknife 2 = 96 species). Given the high spatio-temporal variability of the composition of the pollinator community, our species list might be incomplete, but the Chao and jackknife indexes indicated that we caught a high proportion of the species richness of these Mediterranean low-vegetation habitats. Nevertheless, a thorough understanding of the pollinator species on Calanques National Park might also include other sampling methods, such as the use of Malaise traps, which is particularly efficient for Diptera (Campbell and Hanula 2007), and field work should also be intensified during periods of the year that are rarely sampled, such as autumn. Likewise, due to the difference in sampling effort across years, we cannot explore long-term population trends.

With the Mediterranean dry climate, bee nesting sites seem to be very diverse, with good opportunities for both belowground-nesting and cavity-nesting bee species (Potts et al. 2005). Indeed, the large available areas of bare soil cover in these areas offers advantageous nesting sites for belowground-nesting species. Cavity-nesting species can build their nests with available dry stems or dead branches (Petanidou and Ellis 1993). Hover fly species were also characteristic of dry Mediterranean low-vegetation habitats, as the larvae of most of the recorded species $(63 \%)$ are intolerant of very wet soils.

\section{Protection Status of Mediterranean Pollinator Species}

According to the IUCN European Red List (Nieto et al. 2014), seven $(3 \%)$ threatened bee species were recorded in our surveys. This number is similar to that found in Port-Cros National Park (Gombault et al. 2018). Among those seven species, three have been found in both protected areas (A. ovatula, L. pygmaeum, and $H$. quadricinctus). We also sampled 47 bee species $(24 \%)$ that are considered data deficient by the IUCN Red List, and no conservation statuses are currently attributed to hover fly or bee fly species. This still demonstrates the need for pollinator surveys to provide population trends and conservation statuses. Indeed, these data are essential for IUCN European Red List updates as well as National Red List establishment, especially because little is known about pollinator species presence in southern France. As few examples, in Calanques National Park, we provided the first national record of Nomada rubricoxa Scharz, 1977 (Hymenoptera: Apidae) in May 2016 (Geslin et al. 2018), and specimens of a new Pelecocera Meigen, 1822 (Diptera: Syrphidae) species were collected in 2017 and 2018. The description of this new Pelecocera species is underway and a publication is in preparation (see Lair et al. 2019).

\section{Interaction Network of the Mediterranean Plant- Pollinator Community}

A plant-pollinator network was built based on two types of data from captures and visitations on plant species and from analyses of the pollen carried by the bees. Pollen analysis may give an important added value to networks. However, in our study, an insufficient number of individuals were analyzed to compare pollen and capture networks.

We found that the Cistaceae species in Calanques National Park acted as a central node in the network and were especially represented by three species of Cistus (Malvales: Cistaceae): C. albidus L., C. monspeliensis L., and, to a lesser extent, C. salviifolius L. These species are known to provide both pollen and nectar resources for both bees and hover flies (Bosch 1992), and in the present network, they support 52 pollinator species. Cistus species produce large open flowers and can be easily visited by short and long-tongued pollinators, which makes them generalist species. Our results show that these species are of great importance for a high richness of pollinators in Mediterranean habitats. The Lamiaceae family is also known to be attractive for many pollinator species within Mediterranean habitats, especially because tubular flowers provide high amounts of nectar (Petanidou and Vokou 1993, Petanidou et al. 2000). Among Fabaceae, Astragalus tragacantha L. (Fabales: Fabaceae) was the species visited by the highest richness of pollinator species because the field campaign focused on it. This endangered metal-tolerant species is the target of a LIFE Habitats Calanques conservation programme to reinforce in situ populations (Salducci et al. 2019). Additionally, the morphology of the A. tragacantha flower is not adapted to small pollinators, which have difficulty opening its keel and collecting pollen and nectar. Therefore, larger wild bee species are more able to forage on this species. A deeper knowledge of the pollinator guild has been indicated to be essential to provide management advice to 


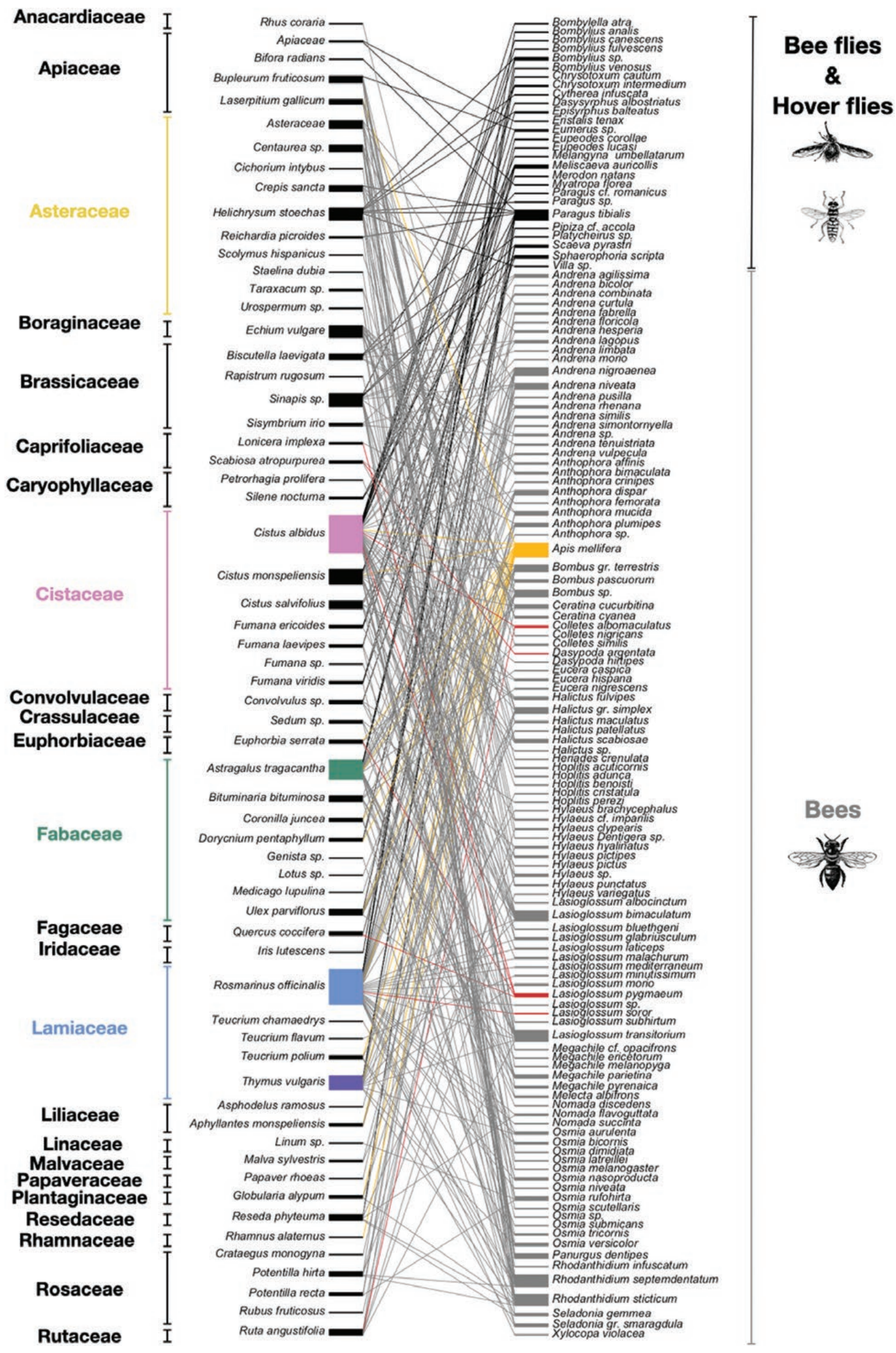

Fig. 2. Interaction network between plant species (left part) and pollinator species (right part) within Calanques National Park. For color figure refer online version. Threatened pollinator species and their links are highlighted in red, while threatened plant species are highlighted in green. Cistus albidus, Rosmarinus officinalis, and Thymus vulgaris, which correspond to the dominant flowering plant species, are colored pink, blue, and purple, respectively. The most generalist and dominant bee species, Apis mellifera, is highlighted in yellow, as are its links. 
build an efficient conservation programme (Schurr et al. 2019). We also found 20 plant species that interacted with only one pollinator species. This can be explained by the low abundance of ruderal plant species, such as Papaver rhoeas L. (Papaverales: Papaveraceae), Rubus fructicosus L. (Rosales: Rosaceae), Medicago lupulina L. (Fabales: Fabaceae), or Crataegus monogyna Jacq. (Rosales: Rosaceae), within the sampled area of Calanques National Park or by the low sampling effort on the nondominant plant species, such as Teucrium chamaedrys L. (Lamiales: Lamiaceae), T. flavum L., Iris lutescens Lam. (Liliales: Iridaceae), and Asphodelus ramosus L. (Liliales: Liliaceae) in the Mediterranean low-vegetation habitats within our sampling sites. As a complement, we found weak nestedness in the network, which indicates that the interactions performed by specialist species were not entirely included as a subset of the interactions realized by generalist species. This shows the importance of specialist species in our network (Almeida-Neto et al. 2008, Ulrich et al. 2009), as they represent $26.5 \%$ of the samplings, including three of the seven threatened bee species. As an example, within the network, we observed D. argentata foraging on Scabiosa (Dipsacales: Caprifoliaceae) species. The other six threatened bee species were generalists or were not linked with a particular plant species in these present surveys. The network indexes, such as modularity and connectance, were consistent with the average metrics of a mutualistic network composed of 195 species (Thebault and Fontaine 2010). Within the mutualistic networks, several studies indicated that the average value of connectance was low to moderate (approximately 0.11 or 0.18 ), and according to Jordano 1987, the connectance values decreased with species richness (Jordano 1987, Landi et al. 2018). The connectance value obtained (0.04) remains difficult to interpret regarding its impact on the stability of the plant-pollinator network. For Thébault and Fontaine (2010), highly connected mutualistic networks are related to high resilience and persistence of the network (Thebault and Fontaine 2010), whereas Allesina and Tang (2012) indicated that connectance destabilizes mutualistic networks (May 1973, Allesina and Tang 2012).

The presence of numerous singletons is very common in ecological surveys, including insect pollinator surveys (Lim et al. 2012). Here, specialist and cleptoparasitic bee species represented half of the bee singletons. Indeed, specialized bee species must feed on their preferred plant species, which decreases the frequency of their captures, especially because some surveys focused on certain plant species in Mediterranean low-vegetation habitats. Cleptoparasitic bees are more difficult to catch because they only visit flowers to gather nectar and fly rapidly close to the ground to find their host's nests (Oertli et al. 2005). However, whereas only $0.5 \%$ of cleptoparasitic bee species were found during the 3-d sampling in 2016 (Geslin et al. 2018 ), we increased this figure to $12 \%$ with the present compilation of surveys. Several studies recorded approximately $17 \%$ of the parasitic bee species in urban or grassland habitats (Oertli et al. 2005, Fortel et al. 2014). The high richness of cleptoparasitic species may indicate that populations of wild bees and their diversity are large enough to support the presence of cleptoparasitic species in this area (Sheffield et al. 2013). Furthermore, no wild bee species were drastically dominant in our survey (Supp Table 1 [online only]), which might suggest a well-structured community (Sheffield et al. 2013, Geslin et al. 2015).

\section{Conclusion}

This survey was an attempt to provide a comprehensive overview of bee, hover fly, and bee fly species richness in a protected area typical of Mediterranean habitats across a $10-\mathrm{yr}$ period (Medail and
Quezel 1999). In addition to these surveys, we believe that some supplementary data coming from museums or private collections could be used to improve this list. In the global context of pollinator decline (Sánchez-Bayo and Wyckhuys 2019), surveys such as ours are especially important, as these taxa represent the main pollinator species in Mediterranean habitats such as phrygana and shrublands (Herrera 1988, 1990). The occurrence and ecological traits of pollinator species should strongly contribute to reinforcing information about species to provide, for example, a conservation status for species still considered as data deficient by the IUCN Red List. We built the plant-pollinator network associated with these habitats to document pollinator diet and their dependency upon floral resources. To further refine this biodiversity inventory, future studies in this area should focus on habitats of community interest, such as Brachypodium (Poales: Poaceae) grasslands or grassland on dolomites, which could be strategic habitats for less abundant or rare pollinator species in our surveys. Preserved or hard-to-reach habitats, such as the small islands (the Maïre, Riou, Plane, and Jarre islands) or the military camps, within the park should also be inventoried. Diversifying the season or the time slot of surveys (e.g., autumnal, nocturnal surveys), as well as the capture methods (e.g., Malaise traps), should lead to more inventoried species. Finally, the networks built from the pollen carried by bees have still been insufficiently explored and could greatly improve and supplement our knowledge of bee floral diets.

\section{Supplementary Data}

Supplementary data are available at Environmental Entomology online.

\section{Acknowledgments}

We are thankful to Calanques National Park, the Observatoire HommesMilieux Littoral méditerranéen (OHM-Littmed), and the AXA postdoctoral fellowship for the financial support. We also thank Calanques National Park and its territory owners for the access permission. We are grateful to E. Dufrêne for the cleptoparasitic bee identifications. We are thankful to C. Lauriaut, B. Tissot, and T. Toth and for hover fly and bee fly identifications. We thank M. Berenger, A. Bideau, P. Caillault, V. Calvert, M. Hamon, A. Maléchaux, J.-Y. Meunier, B. Oursel, M. Panchot, C. Scagliola, A. Syx, and M. Zakardjian, who participated in bee samplings in the field. We are thankful to B. Gauzens for his help in the description of the network. We thank the two anonymous reviewers who made helpful comments on the previous version of the manuscript.

\section{References Cited}

Allesina, S., and S. Tang. 2012. Stability criteria for complex ecosystems. Nature. 483: 205-208.

Almeida-Neto, M., P. Guimarães, P. R. J. Guimarães, R. D. Loyota, and W. Ulrich. 2008. A consistent metric for nestedness analysis in ecological systems: reconciling concept and measurement. Oikos. 117: 1227-1239.

Barber, M. J. 2007. Modularity and community detection in bipartite networks. Phys. Rev. E - Stat. Nonlinear, Soft Matter Phys. 76: 1-9.

Bartomeus, I. 2013. Understanding linkage rules in plant-pollinator networks by using hierarchical models that incorporate pollinator detectability and plant traits. Plos One. 8: e69200.

Bosch, J. 1992. Floral biology and pollinators of three co-occurring Cistus species (Cistaceae). Bot. J. Linn. Soc. 109: 39-55.

Campbell, J. W., and J. L. Hanula. 2007. Efficiency of Malaise traps and colored pan traps for collecting flower visiting insects from three forested ecosystems. J. Insect Conserv. 11: 399-408.

Carré, G. 2008. Biodiversité, paysages et conservation de la communauté d'abeilles dans les agrosystèmes. Université d'Avignon, Avignon, France. 
Chao, A., K. H. Ma, T. C. Hsieh, and C. H. Chiu. 2016. SpadeR (Speciesrichness Prediction And Diversity Estimation in $\mathrm{R}$ ): an $\mathrm{R}$ package in CRAN. Program and User's Guide. http://chao.stat.nthu.edu.tw/blog/ software-download/.

Dafni, A., and C. O’Toole. 1994. Pollination syndromes in the Mediterranean: generalizatoins and peculiarities, pp. 125-135. In M. Arianoutsou, R. H. Groves, (eds.), Plant-Animal Interact. Mediterr. Ecosyst. Kluwer Academic Publishers, The Netherlands.

Dormann, C. F., J. Fründ, N. Blüthgen, and B. Gruber. 2009. Indices, graphs and null models: analyzing bipartite ecological networks. Open J. Ecol. 2: 1 .

Faegri, K., and J. Iversen. 1975. Textbook of pollen analysis. John Wiley and Sons, Chichester. pp. 328.

Faegri, K., P. E. Kaland, and K. Krzywinski. 1989. Textbook of pollen analysis. John Wiley and Sons, Chichester.

Flo, V., J. Bosch, X. Arnan, C. Primante, A. M. Martín González, H. BarrilGraells, and A. Rodrigo. 2018. Yearly fluctuations of flower landscape in a Mediterranean scrubland: consequences for floral resource availability. Plos One. 13: e0191268.

Fortel, L., M. Henry, L. Guilbaud, A. L. Guirao, M. Kuhlmann, H. Mouret, O. Rollin, and B. E. Vaissière. 2014. Decreasing abundance, increasing diversity and changing structure of the wild bee community (Hymenoptera: Anthophila) along an urbanization gradient. Plos One. 9: e104679.

Gargominy, O., S. Tercerie, C. Régnier, T. Ramage, P. Dupont, P. Daszkiewicz, and L. Poncet. 2019. TAXREF v13, référentiel taxonomique pour la France : méthodologie, mise en oeuvre et diffusion. Muséum national d'Histoire naturelle, Paris. Rapport Patrinat. 63 pp.

Genoud, D. 2017. Synthèse des connaissances sur les hyménoptères apoïdes -- Prélèvements 2002 - 2009 et étude 2014. Travaux de la Massane, 108. pp 55 .

Geslin, B., V. Le Féon, M. Kuhlmann, B. E. Vaissière, and I. Dajoz. 2015. The bee fauna of large parks in downtown Paris, France. Ann. Soc. Entomol. Fr. 51, 5-6: 487-493. doi:10.1080/00379271.2016.1146632.

Giorgi, F., and P. Lionello. 2008. Climate change projections for the Mediterranean region. Glob. Planet. Change. 63: 90-104.

Gombault, C., L. Guilbaud, N. Morison, and B. Vaissière. 2018. Inventaires des abeilles sauvages sur les sites de Port-Cros, Bagaud et du cap Lardier. INRA - Parc national de Port-Cros, Avignon, France.

Gotelli, N. J., and R. K. Colwell. 2011. Estimating species richness. Biol. Divers. Front. Meas. Assess. 12: 39-54.

Herrera, J. 1988. Pollination relationships in southern Spanish Mediterranean shrublands. J. Ecol. 76: 274-287.

Herrera, C. M. 1990. Daily patterns of pollinator activity, differential pollinating effectiveness, and floral resource availability, in a summer-flowering mediterranean shrub. Oikos. 58: 277-288.

Jordano, P. 1987. Patterns of mutualistic interactions in pollination and seed dispersal: connectance, dependence asymmetries, and coevolution. Am. Nat. 129: 657-677.

Lair, X., L. Ropars, B. Geslin, E. Minssieux, and G. Nève. 2019. Revision of Pelecocera from France, and description of a new species (Diptera : Syrphidae), p. Poster. In International Symposium of Syrphidae, Greece.

Landi, P., H. O. Minoarivelo, Å. Brännström, C. Hui, and U. Dieckmann. 2018. Complexity and stability of ecological networks: a review of the theory. Popul. Ecol. 60: 319-345

Lim, G. S., M. Balke, and R. Meier. 2012. Determining species boundaries in a world full of rarity: singletons, species delimitation methods. Syst. Biol. 61: $165-169$.

Lugassy, L. 2016. Systèmes de pollinisation et perturbations anthropiques: de l'échelle paysagère à l'échelle macroécologique. Muséum National d'Histoire Naturelle, Paris.

Mariani, M. S., Z. M. Ren, J. Bascompte, and C. J. Tessone. 2019. Nestedness in complex networks: observation, emergence, and implications. Phys. Rep. 813: 1-90.

Martín González, A. M., B. Dalsgaard, and J. M. Olesen. 2010. Centrality measures and the importance of generalist species in pollination networks. Ecol. Complex. 7: 36-43.

May, R. M. 1973. Stability and complexity in model ecosystems. Princeton University Press, Princeton.
Médail, F., and P. Quézel. 1997. Hot-spots analysis for conservation of plant biodiversity in the Mediterranean basin. Ann. Missouri Bot. Gard. 84: $112-127$.

Medail, F., and P. Quezel. 1999. Biodiversity hotspots in the Mediterranean basin: setting global conservation priorities. Conserv. Biol. 13: 1510-1513.

Memmott, J., N. M. Waser, and M. V. Price. 2004. Tolerance of pollination networks to species extinctions. Proc. Biol. Sci. 271: 2605-2611.

Merritt, R. W., G. W. Courtney, and J. B. Keiper. 2009. Diptera, pp. 284-297. In H. R. Vincent, and T. C. Ring (eds.), Encyclopedia of Insects. Academic press, San Diego, CA.

Molinier, R. 1934. Etudes phytosociologiques et écologiques en Provence Occidentale, Ann. Du Musée d'Histoire Nat. Marseille. France. XXVII, Mém. I.

Nielsen, A., I. Steffan-Dewenter, C. Westphal, O. Messinger, S. G. Potts, S. P. M. Roberts, J. Settele, H. Szentgyörgyi, B. E. Vaissière, M. Vaitis, et al. 2011. Assessing bee species richness in two Mediterranean communities: importance of habitat type and sampling techniques. Ecol. Res. 26: 969-983.

Nieto, A., S. P. M. Roberts, J. Kemp, P. Rasmont, M. Kuhlmann, M. G. Criado, J. C. Biesmeijer, P. Bogusch, H. H. Dathe, P. De Rúa, et al. 2014. European Red List of Bees. Publication Office of the European Union, Luxembourg.

Oertli, S., A. Müller, and S. Dorn. 2005. Ecological and seasonal patterns in the diversity of a species-rich bee assemblage (Hymenoptera: Apoidea: Apiformes). Eur. J. Entomol. 102: 53-63.

Ollerton, J. 2017. Pollinator diversity: distribution, ecological function, and conservation. Annu. Rev. Ecol. Evol. Syst. 48: 353-376.

Ollerton, J., R. Winfree, and S. Tarrant. 2011. How many flowering plants are pollinated by animals? Oikos. 120: 321-326.

Petanidou, T., and W. N. Ellis. 1993. Pollinating fauna of a phryganic ecosystem: composition and diversity. Biodivers. Lett. 1: 9-22.

Petanidou, T., and W. N. Ellis. 1997. Interdependence of native bee faunas and floras in changing Mediterranean communities, pp. 201-226. In A. Matheson, S. L. Buchmann, C. O’Toole, P. Westrich, and I. H. Williams (eds.), The conservation of bees. Linnean Society Symposium Series No. 18. Academic Press, London.

Petanidou, T., and D. Vokou. 1993. Pollination ecology of Labiatae in a phryganic (East Mediterranean) ecosystem. Am. J. Bot. 80: 892-899.

Petanidou, T., V. Goethals, and E. Smets. 2000. Nectary structure of Labiatae in relation to their nectar secretion and characteristics in a Mediterranean shrub community ? Does flowering time matter? Plant Syst. Evol. 225: 103-118.

Petanidou, T., A. Vujić, and W. N. Ellis. 2011. Hoverfly diversity (Diptera: Syrphidae) in a Mediterranean scrub community near Athens, Greece. Ann. la Soc. Entomol. Fr. 47: 168-175.

Pires, M., and D. Pavon. 2018. La Flore remarquable des Bouches du Rhône. Plantes, milieux naturels et paysages. Biotope éditions, Mèze, p. 468.

Pocock, M. J. O., O. Johnson, and D. Wasiuk. 2011. Succinctly assessing the topological importance of species in flower-pollinator networks. Ecol. Complex. 8: 265-272.

Poisot, T., and D. Gravel. 2014. When is an ecological network complex? Connectance drives degree distribution and emerging network properties. Peerj. 2: e251.

Popic, T. J., Y. C. Davila, and G. M. Wardle. 2013. Evaluation of common methods for sampling invertebrate pollinator assemblages: net sampling out-perform pan traps. Plos One. 8: e66665.

Potts, S. G., B. Vulliamy, S. Roberts, C. O’Toole, A. Dafni, G. Ne'eman, and P. Willmer. 2005. Role of nesting resources in organising diverse bee communities in a Mediterranean landscape. Ecol. Entomol. 30: 78-85.

R Core Team. 2019. R: A language and environment for statistical computing. R Foundation for Statistical Computing, Vienna, Austria.

Rader, R., I. Bartomeus, L. A. Garibaldi, M. P. Garratt, B. G. Howlett, R. Winfree, S. A. Cunningham, M. M. Mayfield, A. D. Arthur, G. K. Andersson, et al. 2016. Non-bee insects are important contributors to global crop pollination. Proc. Natl Acad. Sci. USA. 113: 146-151.

Rasmont, P., J. Devalez, A. Pauly, D. Michez, and V. G. Radchenko. 2017. Addition to the checklist of IUCN European wild bees (Hymenoptera: Apoidea). Ann. la Société Entomol. Fr. 53: 17-32.

Reille, M. 1999. Pollen et spores d'Europe et d'Afrique du nord. Laboratoire de botanique historique et palynologie, Marseille, France. pp. 535. 
Ropars, L., I. Dajoz, and B. Geslin. 2018. La diversité des abeilles parisiennes. Osmia. 7: 14-19.

Ropars, L., L. Affre, L. Schurr, F. Flacher, D. Genoud, C. Mutillod, and B. Geslin. 2020. Land cover composition, local plant community composition and honeybee colony density affect wild bee species assemblages in a Mediterranean biodiversity hot-spot. Acta Oecologica. 104: 103546.

Salducci, M. D., H. Folzer, J. Issartel, J. Rabier, V. Masotti, P. Prudent, L. Affre, L. Hardion, T. Tatoni, and I. Laffont-Schwob. 2019. How can a rare protected plant cope with the metal and metalloid soil pollution resulting from past industrial activities? Phytometabolites, antioxidant activities and root symbiosis involved in the metal tolerance of Astragalus tragacantha. Chemosphere. 217: 887-896.

Sánchez-Bayo, F., and K. A. G. Wyckhuys. 2019. Worldwide decline of the entomofauna: a review of its drivers. Biol. Conserv. 232: 8-27.

Schurr, L., L. Affre, F. Flacher, T. Tatoni, L. Le Mire Pecheux, and B. Geslin. 2019. Pollination insights for the conservation of a rare threatened plant species, Astragalus tragacantha (Fabaceae). Biodivers. Conserv. 28: 1389-1409.

Sheffield, C. S., A. Pindar, L. Packer, and P. G. Kevan. 2013. The potential of cleptoparasitic bees as indicator taxa for assessing bee communities. Apidologie. 44: 501-510.
Sommaggio, D. 1999. Syrphidae: can they be used as environmental bioindicators? Agric. Ecosyst. Environ. 74: 343-356.

Thébault, E., and C. Fontaine. 2010. Stability of ecological communities and the architecture of mutualistic and trophic networks. Science. 329: 853-856.

Ulrich, W., M. Almeida-Neto, and N. J. Gotelli. 2009. A consumer's guide to nestedness analysis. Oikos. 118: 3-17.

Weiner, C. N., M. Werner, K. E. Linsenmair, and N. Blüthgen. 2014. Land-use impacts on plant-pollinator networks: interaction strength and specialization predict pollinator declines. Ecology. 95: 466-474.

Westphal, C., R. Bommarco, G. Carré, E. Lamborn, N. Morison, T. Petanidou, S. G. Potts, S. P. M. Roberts, H. Szentgyörgyi, T. Tscheulin, et al. 2008. Measuring bee diversity in different European habitats and biogeographical regions. Ecol. Monogr. 78: 653-671.

Wilson, J. S., T. Griswold, and O. J. Messinger. 2008. Sampling bee communities (Hymenoptera: Apiformes) in a desert landscape: are pan traps sufficient? J. Kansas Entomol. Soc. 81: 288-300.

Zaitzev, V. F. 2007. Contributions to the Palaearctic fauna of the dipteran families Bombyliidae and Mythicomyiidae (Diptera): I. Entomol. Rev. 87: 159-173.

Zaitzev, V. F. 2008. Contributions to the Palaearctic fauna of the dipteran families bombyliidae and mythicomyiidae (Diptera): II. Entomol. Rev. 88: 186-198. 